\title{
Assessment on the Outcome of the Pantawid Pamilyang Pilipino Program in Tabuk City, Kalinga
}

\section{Jane Chad-en B. Busaing}

Kalinga State University, Philippines

Received: 07 Oct 2020; Received in revised form: 22 Dec 2020; Accepted: 28 Dec 2020; Available online: 31 Dec 2020

(C)2020 The Author(s). Published by Infogain Publication. This is an open access article under the CC BY license

(https://creativecommons.org/licenses/by/4.0/).

Abstract - This study assessed the outcome of Pantawid Pamilyang Pilipino Program in Tabuk City, Kalinga. Towards this goal, it determined the following: level of attainment of the program's objectives; extent of compliance of the grantees on program's conditions; degree of seriousness of problems encountered in its implementation; and its performance indicators along health and nutrition, and education.

The research design involved the use of descriptive survey method, documentary analysis, interview, and focus group discussion (FGD) in order to collect data on the outcome of Pantawid Pamilyang Pilipino Program in Tabuk City, Kalinga. The respondents are the Pantawid Pamilya Program beneficiaries, implementers and community in Tabuk City, Kalinga. The questionnaire was utilized in gathering data about the attainment of the goals and objectives of the program; extent of compliance on program conditions; and, the degree of seriousness of problems encountered in the implementation of the Pantawid Pamilya. Analysis of data was limited to the use of frequency counts, percentages, weighted means, and analysis of variance (ANOVA).

Findings revealed show that the respondents claimed that the objectives of Pantawid Pamilyang Pilipino Program were very much attained; the program conditions were very much complied; and problems encountered in its implementation were less serious. Analysis of variance result revealed that there was no significant difference on the perception of the beneficiaries, implementers and community on the level of attainment of the objectives of Pantawid Pamilyang Pilipino Program.

The result of analysis of variance revealed that there was no significant difference on the perception of the respondents on the: level of attainment of the program's objectives; extent of compliance of the conditionalities/conditions of the program; and degree of problems encountered in the implementation of the Program. Documentary analysis on health and nutrition revealed that all pregnant household members complied and completed the required number of prenatal visits; they give birth to RHUs and lying in clinics in the locality which were attended by healthcare professionals; postpartum follow-up care was provided; no maternal complications and postpartum complications were seen and observed; Pantawid Pamilya children were vaccinated; consultation services were rendered; and regular weight monitoring was provided.

As to education compliance, the grantees were very much complied with the attendance requirement of the program since there is an increase in the enrollment rate of children and consistent attendance rate of higher than $85 \%$ per year.

In line with the findings of the study, the objectives of Pantawid Pamilya Program in Tabuk City, Kalinga were very much attained because most grantees are very much compliant with all the 
International Journal of English Literature and Social Sciences, 5(6)

Nov-Dec 2020 / Available online: https://ijels.com/

conditionalities/conditions of the program. Also, successful outcome of the program is observable despite the less serious problems encountered in its implementation.

Keywords-Pantawid Pamilyang Pilipino, education compliance, healthcare.

\section{INTRODUCTION}

In line with the provision of the Philippine constitution under article 2, section 9, Jean Jacques Rousseau Social Contract Theory explains that the state exists to ensure or guarantee protection of rights, life, property and liberty. The primary motive is to protect the rights of citizens in the community which means safeguarding their rights, as what Rousseau called as the general will. One of the interventions done by the state in order to protect life and combat poverty was the enactment of the Pantawid Pamilyang Pilipino Program. The program is a social contract where a state provides resources to a family in exchange for that family's fulfillment of certain conditions set by the government.

Based on the study of Judith Sagayo in Pasil, Kalinga for the year 2014, it revealed a full attainment of the objectives of the program and shown that the problems encountered during the full blast implementation of the program resulted to less serious. Also, the study of Tongay in 2016, entitled "Pantawid Pamilyang Pilipino Program in the Municipality of Balbalan, Kalinga". One of its objectives is to evaluate the attainment of Pantawid Pamilya objectives. The findings revealed that Pantawid Pamilya in Balbalan, Kalinga was much attained. This shows that implementers in the said Municipality have been conducting a series of activities for the beneficiaries as reflected by the MSWD Report in 2015 . Also, there is an active participation of the beneficiaries for the activities.

Similar evaluation study of Pantawid Pamilya in Iloilo which was conducted by Frufonga (2016) of West Visayas State University which measured the attainment of Pantawid Pamilya objectives. Results revealed that there was evidence of improvement in the preventive healthcare among pregnant women and younger children. Improvement was observed in the reduction of malnourished children. Result also showed an increase in the enrollment of children in public schools and the attendance rate of children was increased. Decreased incidence of child labor was observable among children. The decrease to nearly $0 \%$ in the drop-out rate of school children was an indication of improvement. Moreover, the results showed that the beneficiaries spent the largest amount of income on food, followed by education, hospitalization, and savings. In the same manner, the program increased parents' participation in the Family Development Sessions to nearly $100 \%$.

Positive result is also revealed in the first phase of this study in 2018 entitled "Pantawid Pamilyang Pilipino Program in Selected Barangays of Tabuk City, Kalinga" with an objective of measuring the extent of benefits derived from the program. The findings discovered that the overall conditionalities/benefits derived from the program as perceived by the respondents were very much benefited. This implies that the program provided all the necessary benefits of a grantee in the selected Barangays in Tabuk City. According to the respondents, the program provided allowances for their children at the same time they are being prioritized for health and education benefits in their barangays.

However, the Pantawid Pamilya program in the province of Kalinga has been encountered some minor issues and problems. But as perceived by the respondents' majority are not serious. There are only few highlights of problems which were being emphasized by some studies from 20142018. Like the study of Sagayo, the problems being emphasized were "no follow-up or monitoring of children's performance in school", and some beneficiaries are not really poor or indigent". It was explained that there is no strict monitoring of Pantawid Pamilya children's school performance or the implementers are lenient for checking the attendance of the children of beneficiaries. Also, the researcher divulged that there are beneficiaries who are employed and still enjoying the benefits of the program. The scenario in these cases, one of the couples is employed while the other is unemployed or self-employed as farmer. In order to retain full membership, the unemployed was placed as the head of the family.

Other concerns as revealed in the study of Tongay, the degree of seriousness of problems encountered in the implementation of the Pantawid Pamilya in Balbalan, Kalinga was perceived as moderately serious. The findings indicate that the implementers perceived that the problems were moderately serious because they want to fully implement the expected over-all benefits of the program. They focus on the problems of ATM cards/ alternative payment systems. The LGU of Balbalan even brings the beneficiaries to Tabuk City 
using the LGU vehicle just to let them minimize any expenses and they also invited once a bank representative from Tabuk City to give payouts.

While in Tabuk City, based on the first phase of this study, the top 3 highest problems encountered as perceived by the respondents are "Pawning of Pantawid Pamilya ATM cards" was marked as moderately serious, followed by "Discrepancy and inconsistency in the selection and validation of beneficiaries" which is interpreted as less serious, and the third one is "Using children's allowance in buying other things instead of school and nutritional needs".

Despite the presence of problems in the implementation of the Pantawid Pamilya, its outcome is greater than those issues encountered.Recently in the year 2017, a qualitative investigation on the outcome of 4Ps conducted by Garcines which emphasized that there are testimonies of teachers and heads who admitted the 4Ps children before the 4Ps implementation, the recipients are non-compliant with school requirements and sporadic in class participation. They even added that they found them engage their children in labor. But after Pantawid implementation, they observed improvement on these children's attendance and involvement in school undertaking.

Also, in the same year, Sanchez, conducted an "Assessment of Family Development Session of the 4Ps: Contents, Process and Effects". The study reveals that the respondents perceive the FDS as significant and useful, particularly in the aspect of knowledge an acquisition. They also have high regard for implementers and have a positive review of the implementers' ability to deliver the topics and deal with beneficiaries agreeably.

Based from the above-mentioned researches findings, this study provides a more in-depth assessment of Pantawid Pamilya outcomes through a combination of quantitative and qualitative measurements. The quantitative findings will be substantiated by qualitative investigation, and documentary analysis. Thus, this study assessed the outcome of implementing the Pantawid Pamilya in Tabuk City, Kalinga through the investigating the attainment of the objectives of the program, the extent of compliance of grantees on program conditions, and the degree of seriousness of problems encountered in the implementation of the program.

\section{METHODOLOGY}

The study is a mixed method of research (quantitative and qualitative) that utilized the descriptive survey method guided with questionnaire, interview, observation, documentary analysis, and focus group discussion (FGD) in order to collect data on the implementation of Pantawid Pamilyang Pilipino Program in Tabuk City, Kalinga.

The study was conducted in all clustered barangays of Tabuk City, Kalinga namely: Northern Tabuk City (Magsaysay), Eastern Tabuk City (Bulo), Western Tabuk City (Bado Dangwa), and Southern Tabuk City (Cudal). The respondents were the Pantawid Pamilya beneficiaries, program implementers, and the community. All in all, there were 850 respondents.

In this study, the questionnaire was the primary tool in gathering data on the level of attainment of the objectives of the program, level of compliance on program conditions, and the degree of seriousness of problems encountered in the implementation of the Pantawid Pamilya. Since majority of the contents of the questionnaire were being lifted from the Pantawid Pamilya Operation Manual, and other previous studies, it was deemed valid and reliable.

Before the full blast of data gathering, permission granted from City Mayor's Office, DSWD Regional Office of CAR, Tabuk City Social Welfare and Development Office (CSWD), DepEd, Barangay Chairmen, School Principals, and Barangay Midwives.

The researcher with the help of enumerators, personally administered and retrieved the questionnaires from the respondents. From the retrieved questionnaires, gathered information and data were collated and tabulated for statistical treatment. Analysis of data was limited to the use of frequency counts, percentages, weighted means, and analysis of variance (ANOVA).

\section{RESULTS AND DISCUSSION}

\section{Level of Attainment of the Objectives of the Pamilyang Pilipino Program}

As presented in table 2, the objectives of the Pantawid Pamilya Program were very much attained since the total average weighted mean is 4.25 which implies that the program greatly helped in improving the health, nutrition, and educational status of the beneficiaries in Tabuk City, Kalinga. 
The findings revealed that health care is being ensured among women and children in Tabuk City, Kalinga. The result affirms the findings of Sagayo (2014) in Pasil, Kalinga since it also revealed a fully attainment of the objectives of Pantawid Pamilya Program. This implies that the program has helped in improving the socio-economic status of the indigent families. The program also helped in maintaining the health and nutrition of the children, improving their school attendance, and raising their academic performance.
Also, it affirms the research evaluation of Frufonga (2016) in Iloilo wherein parents were encouraged in investing in their children's health, education, and participation to community activities. This was substantiated by the improvement in the preventive healthcare among pregnant women and younger children; there is evident of reduction of malnourished children; there is an increase in the enrollment of children in public schools and the attendance rate of children; the beneficiaries spent the largest amount of income on food, followed by education, hospitalization, and savings; and the program increased parents' participation in the Family Development Sessions to nearly $100 \%$.

Table 2. Level of attainment of the objectives of Pantawid Pamilyang Pilipino Program.

\begin{tabular}{llc}
\hline Objectives of & WM & D \\
\hline & & \\
1. Improve preventive health care among pregnant women and young children. & 4.51 & VMA \\
2. Increase the enrolment and attendance rate of children in school. & 4.26 & VMA \\
3. Reduce incident of child labor. & 3.98 & MA \\
$\begin{array}{l}\text { 4. Raise the average household consumption in food expenditure of poor household. } \\
\text { 5. Encourage parents to invest in their children's and their own human capital through } \\
\text { investments in their health, education and nutrition and participation to community } \\
\text { activities. }\end{array}$ & 4.17 & MA
\end{tabular}

\begin{tabular}{lcc}
\hline \hline Average Weighted Mean & 4.25 & VMA \\
\hline
\end{tabular}

Legend: VMA-Very Much Attained MA-Much Attained WM-Weighted Mean

Table 2.1 indicate that respondents have differences on their perceptions on the level of attainment of objectives of Pantawid Pamilya Program. The beneficiaries perceived that the five objectives of Pantawid Pamilya Program were very much attained. As claimed by most beneficiaries, even if the amount granted to them is meager to augment their family income, it still alleviates their financial burden. In addition, majority of the beneficiaries in Tabuk City, Kalinga were motivated to improve their ways in attending and providing the basic needs of their children.

The implementers are having a slight distinct assessment on the level of attainment of the objectives of Pantawid Pamilya Program. They perceived that most of the objectives of the program were much attained except for the objective "reduce incident of child labor". Though there were no records of child labor, there were some teachers who observed some actual scenarios of child labor in the locality during their follow up activities for some problematic pupils/students. As claimed, a grade two pupil takes care for her infant sibling for the whole day when their parents are out to look for living. This is actually happening during planting and harvesting seasons in the barrios. But majority of the implementers claimed a very much attained objective for the reduction of child labor. They reason out that there are actual cases of child labor but the health and educational needs of their children were not compromised and no records of child labor in the locality. This observable reduction of child labor in Tabuk City was also similar with the result of the evaluation of Pantawid Pamilya conducted by Frufonga (2016) in Iloilo.

The community perceived that majority of the objectives of the program are much attained for the "increase of enrolment and attendance rate of children in school", "reduce child labor", and "raise the average household consumption on food of poor household" with weighted means of $4.11,3.53$, and 4 which indicates a much-attained objective. They claimed that there is still presence of 
absenteeism among grantees children and not strictly monitored. They stated that they observed some children roaming and playing around the barrios during school hours. Also, child labor is somewhat part of our indigenous culture that we need to help our parents to look for living so reduction of it will not be done easily. Lastly, though the cash grant is a great help for grantees to raise their average household food consumption, some grantees children are not regularly eating nutritious food. As mentioned, some are just relying for the release of the cash grant before they can buy some valuable food for their children.

Table 2.1 Comparison of perceptions of the respondents on the level of attainment of the objectives of Pantawid Pamilya Program

\begin{tabular}{|c|c|c|c|c|c|c|}
\hline \multirow[t]{2}{*}{ Objectives of Pantawid Pamilya Program } & \multicolumn{2}{|c|}{ Beneficiaries } & \multicolumn{2}{|c|}{ Implementers } & \multicolumn{2}{|c|}{ Community } \\
\hline & $\begin{array}{c}\text { WM } \\
\text { (B) }\end{array}$ & $\mathrm{D}$ & $\begin{array}{c}\text { WM } \\
\text { (I) }\end{array}$ & $\mathrm{D}$ & $\begin{array}{c}\text { WM } \\
\text { (C) }\end{array}$ & $\mathrm{D}$ \\
\hline $\begin{array}{l}\text { 1. Improve preventive health care among } \\
\text { pregnant women and young children. }\end{array}$ & 4.56 & VMA & 4.16 & MA & 4.50 & VMA \\
\hline $\begin{array}{l}\text { 2. Increase the enrolment and attendance rate } \\
\text { of children in school. }\end{array}$ & 4.42 & VMA & 4.24 & VMA & 4.10 & MA \\
\hline 3. Reduce incident of child labor. & 4.39 & MA & 4.24 & VMA & 3.53 & MA \\
\hline $\begin{array}{l}\text { 4. Raise the average household consumption in } \\
\text { food expenditure of poor household. }\end{array}$ & 4.39 & MA & 3.88 & MA & 3.99 & MA \\
\hline $\begin{array}{l}\text { 5. Encourage parents to invest in their } \\
\text { children's and their own human capital through } \\
\text { investments in their health, education and } \\
\text { nutrition and participation to community } \\
\text { activities. }\end{array}$ & 4.47 & VMA & 3.72 & MA & 4.23 & VMA \\
\hline Average Weighted Mean & 4.44 & " VMA & 4.04 & MA & 4.07 & 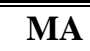 \\
\hline
\end{tabular}

\section{Summary of ANOVA on the Level of Attainment of the Objectives of Pantawid Pamilyang Pilipino Program}

The analysis of variance in table 2.2 hypothesized that there is no difference in the assessment of the three groups of respondents on the level of attainment of the objectives of the Pantawid Pamilya Program. The results analysis of variance shows that the computed F-Ratio of 49.218 has an associated probability of 0.00 . For this reason, the null hypothesis is rejected.

Table 2.2. Summary of ANOVA on the Level of Attainment of the Objectives of Pantawid Pamilyang Pilipino Program.

\begin{tabular}{lccccc}
\hline Source of variance & Sum of Squares & df & Mean Square & F-Ratio & Sig. \\
\hline Between Groups & 30.290 & 2 & 15.145 & 49.218 & .000 \\
Within Groups & 260.635 & 847 & .308 & & \\
\hline \hline Total & 290.925 & 849 & & & \\
\hline
\end{tabular}

* significant at 0.01 
The weighted means of the three groups under table 2.1, the beneficiaries with a weighted mean of 4.44 gave the highest score with a descriptive equivalent of very much attainment. The other two groups had a lower weighted means of 4.04 (implementers) and 4.07 (community). The finding is attributed to the fact that beneficiaries recognized that the program is a big financial help to them.

\section{Extent of Compliance on the Conditionalities of Pantawid Pamilyang Pilipino Program in Tabuk City, Kalinga}

Health and Nutrition.

The respondents claimed health and nutrition

conditions were very much complied since the Pantawid

Table 3. Extent of compliance of beneficiaries on the conditionalities of Pantawid Pamilyang Pilipino Program.
Pamilya Program was implemented. There were no cases of maternal complications during pregnancies among Pantawid Pamilya households' members and common illnesses of children were managed immediately. Also, the grant for health was utilized to buy basic health needs like vitamins and nutritious foods for their children; and they availed the free monthly health visits in the RHU.

Education.

As perceived, the educational conditions of the program were much complied. This implies that there are some beneficiaries that are not compliant to the fourth educational requirement of the program.

\section{Pantawid Pamilya Conditions}

\section{Health and Nutrition}

1. Pregnant beneficiaries household members availed pre and post-natal care.

2. Children 0-5 years old household members availed immunization.

3. Children 0-2 years old household members availed monthly weight monitoring and nutrition counseling.

4. Children 6-14 years old household members availed deworming twice a year.

5. Household beneficiaries receive a health grant / FDS grant of 500 per month if they complied with the conditions.

6. Household grantees attend a once a month Family Development Session to enhance knowledge and skills in responding parental roles and responsibilities on health and nutrition needs of children.

\section{Education}

1. Grantees' Children 3-5 years old household members were enrolled to day care or preschool program and maintain a class attendance rate of at least $85 \%$ per month.

2. Grantees' Children 6-18 years old household members were enrolled in elementary and secondary schools and maintain a class attendance rate of at least $85 \%$ per month.

3. Household members with elementary children including day care and pre-school children receive a grant for education of $\mathrm{P} 300$ per month while Household members with secondary children receive a grant for education of P500 per month.

4. Household grantees attend to once a month Family Development Session to enhance knowledge and skills in responding parental roles and responsibilities on education needs of children.

\section{WM}

D

$\begin{array}{ll}4.62 & \text { VMC } \\ 4.58 & \text { VMC } \\ 4.45 & \text { VMC }\end{array}$

$\begin{array}{lr}3.58 & \mathrm{MC} \\ 4.36 & \mathrm{VMC}\end{array}$

$4.34 \quad$ VMC

$4.26 \quad$ VMC

$4.05 \quad \mathrm{MC}$

$4.60 \quad$ VMC

$4.18 \quad$ MC
Average Weighted Mean

Legend: VMC-Very Much Complied $\quad$ MC-Much Complied $\quad$ WM -Weighted Mean

4.30

VMC 
Despite the differences on the perceptions of the respondents, the table revealed that majority of the educational conditions of the program were very much complied by the beneficiaries.

\section{Comparison on the Perceptions of the Respondents on the Level of Compliance on the Conditionalities/ Benefits of Pantawid Pamilyang Pilipino Program}

The beneficiaries perceived that all the conditions of the program were very much complied. The result implies that beneficiaries are compliant with all the health and nutritional conditionalities of the program. This result confirmed the compliance report of DSWD SWAD office of Kalinga for the year 2012-2018.

Contrary to the perception of the beneficiaries, the implementers perceived that majority of the health and education conditionalities were much availed except for health and nutrition conditions no. 1 "Pregnant beneficiaries household members availed pre and post-natal care" got the highest response as complied since its weighted is 4.42 which means very much complied, followed by the condition "Children 0-5 years old household members availed immunization" which got a weighted mean of 4.22 indicating a very much complied condition. Also, for education conditions, the condition "Grantees' Children 3-5 years old and 6- 18 years old household members were enrolled in elementary and secondary schools and maintain a class attendance rate of at least $85 \%$ per month" is the most complied educational condition as evidenced by a weighted mean of 4.24. This implies that Pantawid parents were encouraged and motivated to send their children in the school. While the least complied educational condition was "Household grantees attend to once a month Family Development Session to enhance knowledge and skills in responding parental roles and responsibilities on education needs of children" with a weighted mean of 2.54 which means less complied. This confirms the claims of some parent leaders that there are some non-compliant grantees with FDS due to behavioral reasons and unavoidable situations that they cannot be available during FDS schedule.

Just like the beneficiaries, the neighboring residents (community) of the beneficiaries claimed that majority of the conditions of the program perceived that the conditions are very much complied by the grantees. except for the condition "Children 6-14 years old household members availed deworming twice a year", the community perceived as moderately complied as evidenced by a weighted mean of 2.78. This implies that as per observation by the grantees' neighbors, majority of the beneficiaries are compliant with the conditionalities of the program.

Table 3.1. Comparison on the perceptions of the respondents on the extent of compliance of grantees on the conditionalities of Pantawid Pamilyang Pilipino Program

$\mathbf{P}$

\section{Beneficiaries}

$\mathrm{D}$
Implementers

WM

$\mathrm{D}$
VMC

VMC

VMC

VMC

3. Children 0-2 years old household members availed monthly weight monitoring and nutrition counseling.

4. Children 6-14 years old household members availed deworming twice a year.

5. Household beneficiaries receive a health grant / FDS grant of 500 per month if they complied with the conditions.

$\begin{array}{llllll}4.59 & \text { VMC } & 4.42 & \text { VMC } & 4.67 & \text { VMC } \\ 4.68 & \text { VMC } & 4.22 & \text { VMC } & 4.52 & \text { VMC } \\ 4.50 & \text { VMC } & 4.18 & \text { MC } & 4.44 & \text { MA } \\ & & & & & \\ 4.33 & \text { VMC } & 3.98 & \text { MC } & 2.78 & \text { MoC } \\ 4.35 & \text { VMC } & 3.82 & \text { MC } & 4.44 & \text { VMC }\end{array}$


6. Household grantees attend a once a month Family Development Session to enhance knowledge and skills in responding parental roles and responsibilities on health and nutrition needs of children.

\section{Education}

1. Grantees' Children 3-5 years old household members were enrolled to day care or preschool program and maintain a class attendance rate of at least $85 \%$ per month.

2. Grantees' Children 6-18 years old household members were enrolled in elementary and secondary schools and maintain a class attendance rate of at least $85 \%$ per month.

3. Household members with elementary children including day care and pre-school children receive a grant for education of $\mathrm{P} 300$ per month while Household members with secondary children receive a grant for education of P500 per month.

4. Household grantees attend to once a month Family Development Session to enhance knowledge and skills in responding parental roles and responsibilities on education needs of children.
4.55
VMC
3.68
$\mathrm{MC}$
VMC

$\begin{array}{lllll}4.31 & \mathrm{VMC} & 4.24 & \mathrm{VMC} & 4.20\end{array}$

$\begin{array}{lllll}4.14 & \mathrm{MC} & 4.06 & \mathrm{MC} & 3.96\end{array}$

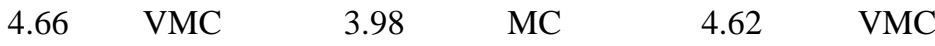

$\begin{array}{llllll}4.47 & \text { VMC } & 2.54 & \text { LC } & 4.10 & \text { MC }\end{array}$

\begin{tabular}{|c|c|c|c|c|c|c|}
\hline Average Weighted Mean & 4.45 & "VMC & 433.91 & MC & 4.19 & MC \\
\hline
\end{tabular}

Summary of ANOVA on the Extent of Compliance of Beneficiaries on Conditionalities and Benefits of Pantawid Pamilyang Pilipino Program as Perceived by Respondents
The study hypothesized that there is no difference in the assessment of the three groups of respondents on the extent of compliance of grantees of the Pantawid Pamilya Program since the results analysis of variance indicate that the computed F-Ratio of 91.740 has an associated probability of 0.00 . For this reason, the null hypothesis is rejected.

Table 3.2. Summary of ANOVA on the extent compliance of beneficiaries on conditions of Pantawid Pamilyang Pilipino Program.

\begin{tabular}{lccccc}
\hline Source of variance & Sum of squares & Df & Mean of Square & F-Ratio & Sig. \\
\hline Between Groups & 22.244 & 2 & 11.122 & 91.740 & .000 \\
Within Groups & 102.684 & 847 & .121 & & \\
\hline \hline Total & 124.928 & 849 & & \\
\hline
\end{tabular}

* significant at 0.01 
As shown in the weighted means of the three groups under table 3.1, the beneficiaries with a weighted mean of 4.45 gave the highest score with a descriptive equivalent of very much complied. The other two groups had a lower weighted means of 3.91 (implementers) and 4.19 (community). The finding is attributed to the fact that beneficiaries recognized that the program is a big financial help to them so they need to comply strictly to the conditions of the program.

Degree of Seriousness of Problems Encountered in the Implementation of the Pantawid Pamilyang Pilipino Program
As revealed by the result, among the 14 observable problems of the program, the top four problems which were regarded as moderately serious: "Complaint of individuals or households excluded from the beneficiary list who feel they should be included in the program"; "Discrepancy and inconsistency in the selection and validation of beneficiaries"; "Some beneficiaries are not poor or indigent"; and Some grantees are "Not obeying the parent leader as the leader of the parent group".

Table 4. Degree of seriousness of problems encountered in the implementation of the Pantawid Pamilyang Pilipino Program.

\begin{tabular}{|c|c|c|}
\hline Problems Encountered & WM & $\mathbf{D}$ \\
\hline $\begin{array}{l}\text { 1. Complaint of individuals or households excluded from the } \\
\text { beneficiary list who feel they should be included in the program. }\end{array}$ & 3.37 & $\mathrm{MoS}$ \\
\hline 2. Irregular participation of parent beneficiaries during meetings. & 2.42 & LS \\
\hline $\begin{array}{l}\text { 3. Using children's allowance in buying other things instead of } \\
\text { school and nutritional needs. }\end{array}$ & 2.08 & LS \\
\hline 4. Not obeying the parent leader as the leader of the parent group. & 2.69 & $\mathrm{MoS}$ \\
\hline 5. Not attending family counseling. & 2.29 & LS \\
\hline 6. Some beneficiaries are not poor or indigent. & 3.04 & $\mathrm{MoS}$ \\
\hline $\begin{array}{l}\text { 7. Parent beneficiaries do not participate in community meeting } \\
\text { and school activities. }\end{array}$ & 2.25 & LS \\
\hline 8. Pawning of 4P's ATM cards. & 2.13 & LS \\
\hline 9. Difficulty in obtaining cash grant. & 1.71 & NS \\
\hline 10. Reduced cash grant entitlement. & 1.82 & LS \\
\hline 11. Delayed release of cash grant. & 1.95 & LS \\
\hline 12. Problems with cash cards or alternative payment systems. & 2.03 & LS \\
\hline 13. No follow-up or monitoring of children's performance in school. & 2.18 & LS \\
\hline 14. Discrepancy and inconsistency in the selection and validation of beneficiaries. & 3.12 & $\mathrm{MoS}$ \\
\hline Average Weighted Mean & 2.36 & $\overline{\mathrm{LSS}}$ \\
\hline
\end{tabular}

Legend: MoS - Moderately Serious; LS - Less Serious; WM - Weighted Mean

Despite the moderately serious problems as claimed by the four groups of respondents, majority of the problems were regarded as less serious and the problem which was considered not serious is "Difficulty in obtaining cash grant" with a weighted mean of 1.71 . This implies that claiming of cash grant is no longer a problem.
Comparison on the Perceptions of the Beneficiaries, Implementers and Community on the Degree of Seriousness of Problems Encountered in the Implementation of the Pantawid Pamilyang Pilipino Program

Comparison result indicate that there are slight differences on the perceptions of respondents on the degree of 
seriousness of problems encountered in the implementation of Pantawid Pamilya Program in Tabuk City, Kalinga.

According to the beneficiaries, the most concerned problem in the implementation of the program is the presence of "complaint of individuals/households excluded from the beneficiary list who feel they should be included in the program" which is moderately serious. Other problems were all regarded as less serious to not serious.

While for the implementers, the problems "No follow-up or monitoring of children's performance in school" and "Discrepancy and inconsistency in the selection and validation of beneficiaries" were considered moderately serious. But other problems were all perceived as less serious. This result affirms the findings of Sagayo in Pasil Kalinga

Table 4.1. Comparison on the perceptions of the respondents on the degree of seriousness of problems encountered in the implementation of the Pantawid Pamilyang Pilipino Program

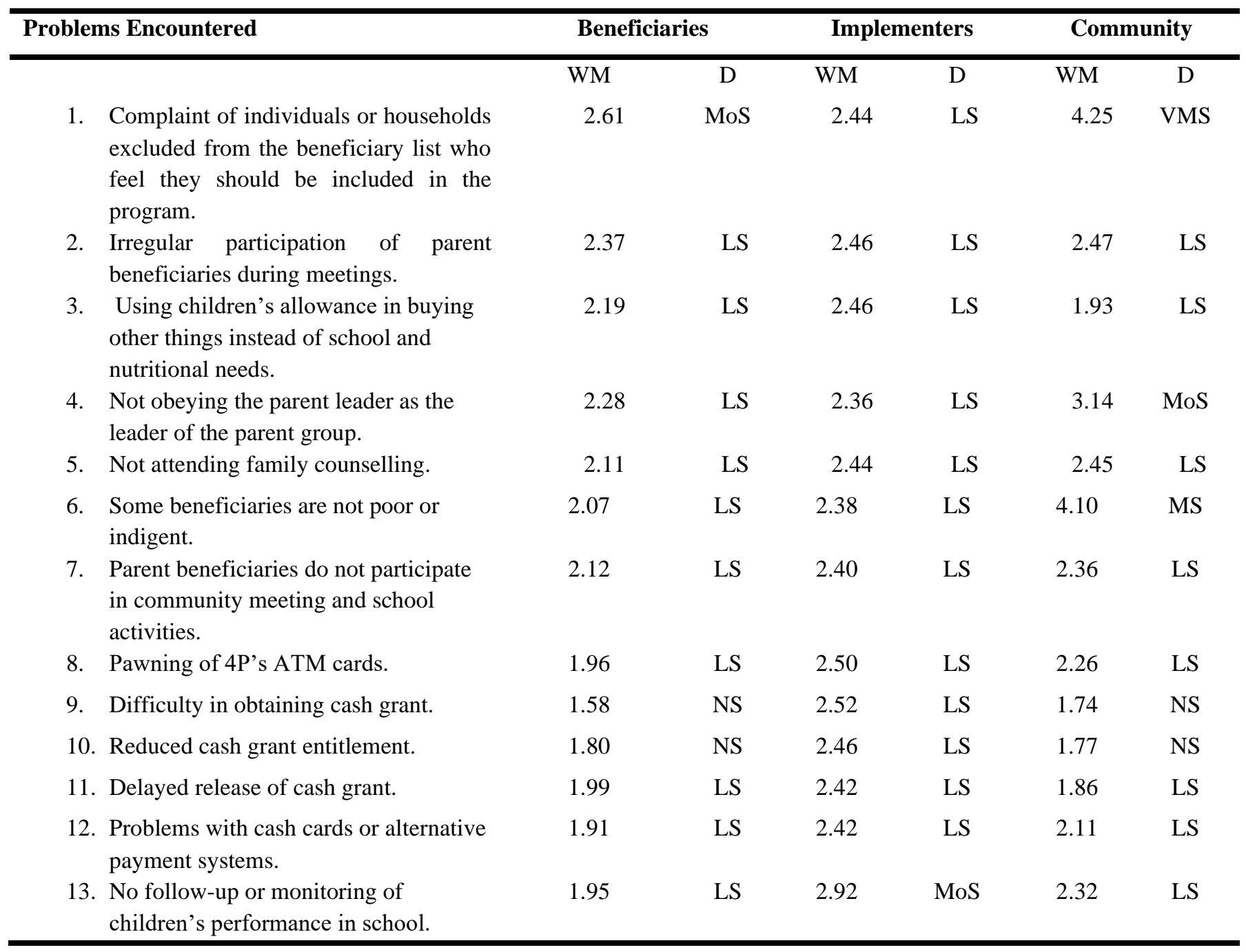




\begin{tabular}{lllllll}
\hline $\begin{array}{l}\text { 14. Discrepancy and inconsistency in the } \\
\text { selection and validation of } \\
\text { beneficiaries. }\end{array}$ & 1.99 & LS & 2.66 & MoS & 4.31 & VMS \\
\hline \hline Average Weighted Mean & $\mathbf{2 . 0 6}$ & LS & $\mathbf{2 . 4 8}$ & LS & $\mathbf{2 . 6 4}$ & MoS \\
\hline
\end{tabular}

Legend: MoS - Moderately Serious; LS - Less Serious; WM - Weighted Mean

To sum up the problems listed in the above table, the two most concerned problems which were regarded as very much serious are "Discrepancy and inconsistency in the selection and validation of beneficiaries" and "Complaint of individuals or households excluded from the beneficiary list who feel they should be included in the program". These was followed by" Some beneficiaries are not poor or indigent". Despite those concerns, still majority of the problems encountered are less serious to not serious.

\section{Summary of ANOVA on the Degree of Seriousness of Problems Encountered in the Implementation of the Pantawid Pamilyang Pilipino}

The study hypothesized that there is no difference in the assessment of the three groups of respondents on the degree of seriousness of problems in the implementation of the Pantawid Pamilya Program. The results analysis of variance shows that the computed F-Ratio of 198.209 has an associated probability of 0.00 . For this reason, the null hypothesis is rejected.

Table 4.2. Summary of ANOVA on the degree of seriousness of problems encountered in the implementation of the Pantawid Pamilyang Pilipino Program

\begin{tabular}{lccccc}
\hline Source of variance & Sum of squares & Df & Mean of Square & F-Ratio & Sig. \\
\hline Between Groups & 68.306 & 2 & 34.153 & 198.209 & .000 \\
Within Groups & 145.944 & 847 & .172 & & \\
\hline \hline Total & $\mathbf{2 1 4 . 2 5 0}$ & $\mathbf{8 4 9}$ & & & \\
\hline
\end{tabular}

* significant at 0.01

As shown in the weighted means of the three groups of respondents under Table 6.1 , the beneficiaries with a weighted mean of 2.06 gave the lowest score with a descriptive equivalent of less serious. The other two groups had a higher weighted means of 2.48 (implementers) and 2.64 (community). The finding is attributed to the fact that beneficiaries were directly benefited from the program so they recognized that the program was well implemented and its problems encountered were manageable and less serious.

Documentary Analysis on Pantawid Pamilyang Pilipino Program on its Attainment of Objectives and Compliance of Grantees

Health and nutrition

Preventive health care for pregnant household beneficiaries

Table 5 indicate that all pregnant household members complied and completed the required number of prenatal visits. Based on records, among the pregnant household members for the year 2012-2018, most of them are under the age bracket of 31-40 years old. This was followed by 21-30 years old which consisted of 43 pregnant mothers then 16 mothers for the 20 years old, and 12 mothers for 41years old and above. All the pregnant mothers' grantees willingly submitted themselves for prenatal check - up at least one visit for first trimester, one visit for $2^{\text {nd }}$ trimester, and two visits for $3^{\text {rd }}$ trimester.

Other needed healthcare services for pregnancy were given like the tetanus toxoid vaccination, regular vital signs monitoring (BP), vitamins (FeSo4, and Folic acid), family planning counseling, and given mothers book for recording of healthcare services rendered. As claimed by the midwives, most these pregnant mothers give birth to RHUs and lying in clinics in the locality which were attended by healthcare professionals like licensed midwives and obstetrician. 
International Journal of English Literature and Social Sciences, 5(6)

Nov-Dec 2020 / Available online: https://ijels.com/

Table 5. Health profile of the Pantawid Pamilya Program pregnant household beneficiaries of three barangays in Tabuk City for the year 2012-2018.

\begin{tabular}{|c|c|c|c|c|c|c|}
\hline \multirow[t]{2}{*}{ Age } & \multirow[t]{2}{*}{$\mathbf{F}$} & \multirow[t]{2}{*}{$\%$} & \multicolumn{3}{|c|}{ Pre- Natal Visit } & \multirow[t]{2}{*}{ Remarks } \\
\hline & & & 1st Trimester & $2^{\text {nd }}$ Trimester & $3^{\text {rd }}$ Trimester & \\
\hline 20 \& below & 16 & $100 \%$ & Complied & Complied & Complied & Completed \\
\hline $21-30$ & 43 & $100 \%$ & Complied & Complied & Complied & Completed \\
\hline $31-40$ & 60 & $100 \%$ & Complied & Complied & Complied & Completed \\
\hline 41-beyond & 12 & $100 \%$ & Complied & Complied & Complied & Completed \\
\hline
\end{tabular}

Based on the Target Client List record of the barangay midwives, postpartum follow-up care was provided like BP monitoring, distribution of multivitamins, hygiene and nutrition health teaching, and bathing of newborn babies. As per record, no postpartum complications were seen and observed.

As gleaned in table 6, the greatest number of pregnancies among Pantawid households in the three barangays of Tabuk City were happened in 2015 with 27 pregnant mothers, in 2016 with 22 numbers of pregnant mothers, in 2014 with 20 pregnancies, in 2013 with19 pregnancies, in 2013 with 16 pregnancies, and in 2018 with 15 pregnancies. The least one is in 2017 with only 12 total pregnancies. According to the midwives, consciousness and compliance for healthcare of pregnant mothers increased when the Pantawid Pamilya Program has started its operation. The data imply that all the pregnant grantees were $100 \%$ compliant with all the healthcare conditions set by the program.

Table 6. Yearly compliance of pregnant beneficiaries for the year 2012-2018.

\begin{tabular}{|c|c|c|c|}
\hline \multirow{2}{*}{ Year } & \multicolumn{2}{|c|}{ Total Number of Pregnant Beneficiaries } & \multirow{2}{*}{ Remarks } \\
\cline { 2 - 4 } & $\mathbf{F}$ & $100 \%$ & Compliant \\
\hline 2012 & 16 & $100 \%$ & Compliant \\
\hline 2013 & 19 & $100 \%$ & Compliant \\
\hline 2014 & 20 & $100 \%$ & Compliant \\
\hline 2015 & 27 & $100 \%$ & Compliant \\
\hline 2016 & 22 & $100 \%$ & Compliant \\
\hline 2017 & 12 & $100 \%$ & Compliant \\
\hline 2018 & 15 & & \multirow{2}{*}{} \\
\hline
\end{tabular}

National Immunization Services (NIPS) for children

Based on interview and immunization record of the barangay midwife of Bado Dangwa, Bulo, and Cudal, Tabuk City, Kalinga, the children of the Pantawid Pamilyang Pilipino Program were vaccinated except one (1) because the mother refuses to submit her child for immunization despite IEC done. Reaching the purok and the house of the grantee has been done by the RHMs, RNs, and BHWs but unfortunately no member of the family was present during the 3-4 times home visits.

\section{Consultation Services}

Consultation services were rendered to Pantawid Pamilya Program household grantees. No serious illnesses among Pantawid children and no maternal complications for pregnant household members. For patients with hypertension (HPN), regular blood pressure monitoring was provided.
Also, monthly maintenance medicines like Losartan, Amlodipine, Metoprolol, and vitamin B complex were given.

Regular monthly check-up was implemented like BP monitoring; distribution of maintenance; glucose monitoring; and weight monitoring for malnourished children and age 0 to 24 months children and given multivitamins, FeSO4 and Micro nutrient provider.

\section{Education}

Table 7 presents the enrolment and attendance data of four elementary schools in Tabuk City, Kalinga. As gleaned from the table, in the school year 2015-2016, the number of Pantawid children enrollees was 1,658 and obtained a $94.25 \%$ attendance rate., followed by 1645 Pantawid enrollees in 2016-2017 with 94.5\% attendance rate; 1552 enrollees in 2017-2018 with 93.25 attendance rate; and 
1505 enrollees in 2018-2019 which obtained the highest attendance rate of $96.25 \%$.

The table indicate that the school year with the most number of enrollees of Pantawid children happened in SY 2015-2016 while the least number of enrollees was in 20182019. This implies a successful indicator because every year there are Pantawid Pamilya children who satisfactory finished their elementary grade. Also, declining of Pantawid children's grantees shows that the number of indigents/eligible families for the program is lowering down. This is an evidence that in Tabuk City, Kalinga, families are surviving from difficulties of poverty.

Table 7. Enrolment data of four elementary schools in Tabuk City, Kalinga for school year 2015-2018.

\begin{tabular}{|c|c|c|c|}
\hline \multirow{2}{*}{$\begin{array}{c}\text { School } \\
\text { Year }\end{array}$} & Number of Enrollees & Pantawid Enrollees & $\begin{array}{c}\text { Attendance Rate } \\
\text { \% }\end{array}$ \\
\cline { 2 - 4 } & 1658 & 530 & 94.25 \\
\hline $2015-2016$ & 1645 & 363 & 94.5 \\
\hline $2016-2017$ & 1552 & 324 & 93.25 \\
\hline $2017-2018$ & 1505 & 241 & 96.25 \\
\hline $2018-2019$ & & & \\
\hline
\end{tabular}

The data also affirm a consistent attendance rate of higher than $85 \%$ attendance rate. This implies that grantees were very much complied as to attendance requirement set by the program.

\section{CONCLUSION}

In line with the findings of the study, the objectives of Pantawid Pamilya Program in Tabuk City, Kalinga are very much attained because most grantees are very much compliant with all the conditionalities of the program. Since the full blast operation of Pantawid Pamilya Program, there are no cases of maternal complications during pregnancies among Pantawid Pamilya households' pregnant members; almost all grantees' children are fully immunized; there is an increase of enrollment rate; there is a consistent attendance rate beyond $85 \%$; and no recorded cases of child labor.

The problems encountered in the implementation of the Pantawid Pilipino Program in Tabuk City, Kalinga is less serious. The most concerned problems by the respondents are "Complaint of individuals or households excluded from the beneficiary list who feel they should be included in the program"; "Discrepancy and inconsistency in the selection and validation of beneficiaries"; "Some beneficiaries are not poor or indigent"; and some grantees are "Not obeying the parent leader as the leader of the parent group". But despite the issues in its implementation, majority of the performance indicators have been achieved which implies a successful outcome of the program.

\section{RECOMMENDATIONS}

Since attainment of the program objectives is evident, continuation of the program is highly recommended.
However, in view of the results of the study, the following were suggested in order to further improve the program.

1. Since child labor is still observable but no one tried to file a case, implementers of the program and other concerned agencies should have a regular and surprise home visitation to monitor child labor in every barangay.

2. Implementers should consider to have a regular and surprise visit to every barangay to validate the health care and education reports of parent leaders, barangay midwives, and teachers. This will give them comparative assessment on the improvement of preventive health care and educational services need of the Pantawid grantees.

3. There should be a community group/ representative in every barangay in the monitoring and evaluation team to help the concerned agencies in assessing if there is really an increase on the enrolment and attendance rate of children in the school and to watch out for child labor cases.

4. Implementers should conduct more IEC strategies in the community in order to explain the qualifications in selection of grantees and conditionalities to maintain their membership in the program. They can do this through per barangay symposium/conference, guesting in 
the radio or television and distribution of Pantawid Pamilya leaflets and operation manuals in the community.

5. Obedience and respect to parent leaders and other authorities should be included on the needed compliance of grantees.

6. Since there are still claims that some beneficiaries are not really indigents, implementers should consider conducting a comprehensive re-validation of the social status of all beneficiaries. In doing this, there will be no claims of bias and discrimination on the selection of eligible household grantees.

\section{ACKNOWLEDGEMENT}

This endeavor was credited to the following people who provided me a boundless assistance and support while conducting this study: Dr. Florentina Dumlao, Dr. Mariden Cauilan, Dr. Marcelo Raquepo, Dr. Dennis Bacuyag, and Nymfa Mae S. Suguitan.

Also, may I extend my deepest gratitude to the Pantawid Pamilya beneficiaries in Barangay Cudal, Bado Dangwa, Magsaysay, and Bulo East, Tabuk City, Kalinga for their valued time and patience in answering the survey questionnaire during the Focus Group Discussion and interview.

Above all, to our Almighty God who provided me wisdom, good health, courage, patience and determination to finish this study.

\section{REFERENCES}

[1] Frufonga, Ronaldo F. (2016). "The 4Ps in Iloilo, Philippines: An Evaluation". West Visayas State University, Janiuay, Iloilo, Philipines. Retrieved March 3, 2019 at 2:31PM from www.apjmr.com/wp-content/uploads/2016/01/APJMR-20153.5.2.08.pdf.

[2] Sagayo, J. (2014). "Pantawid Pamilyang Pilipino Program: Its Implications to the Social Service and Education in Pasil, Kalinga." (Unpublished Master's Thesis) St. Louis College, Bulanao, Tabuk City, Kalinga

[3] Tongay, S. (2016). "Pantawid Pamilyang Pilipino Program in the Municipality of Balbalan, Kalinga”. (Unpublished Master's Thesis) Kalinga State University, Bulanao, Tabuk City, Kalinga

[4] DSWD CAR Report 2014 Conditional Cash Transfer

[5] Department of Social Welfare and Development Report 2012

[6] Pantawid Pamilya Operation Manual

ISSN: $2456-7620$ 